\title{
Boosting the English writing competence through the use of discourse connectors
}

\section{Impulsar la competencia de escritura en inglés mediante el uso de conectores discursivos}

1 Marbella Cumandá Escalante Gamazo (iD) https://orcid.org/0000-0002-3179-8102 Universidad Técnica de Ambato, Carrera de Pedagogía de los Idiomas Nacionales y Extranjeros. Tungurahua, Ecuador, ma.escalante@uta.edu.ec

2 Alba Paulina Hernández Freire https://orcid.org/0000-0002-1618-8330 Universidad Técnica de Ambato, Facultade Ciencias Humanas y la Educación, Carrera de Pedagogía de los Idiomas Nacionales y Extranjeros, Tungurahua, Ecuador, albaphernandezf@uta.edu.ec

3 Cristina del Rocío Jordán Buenaño (iD) https://orcid.org/0000-0003-1938-1379 Universidad Técnica de Ambato, Facultade Ciencias Humanas y la Educación, Carrera de Pedagogía de los Idiomas Nacionales y Extranjeros, Tungurahua, Ecuador, cristinadjordanb@uta.edu.ec

4 Ana Jazmina Vera de la Torre

(iD) https://orcid.org/0000-0003-4698-6242. Universidad Técnica de Ambato, Facultade Ciencias Humanas y la Educación, Carrera de Pedagogía de los Idiomas Nacionales y Extranjeros, Tungurahua, Ecuador, aj@uta.edu.ec

Artículo de Investigación Científica y Tecnológica Enviado: 24/12/2021

Revisado: $29 / 12 / 2021$

Aceptado: 12/01/2022

Publicado:08/03/2023

DOI: https://doi.org/10.33262/concienciadigital.v6i1.4.1988
Cítese:
Escalante Gamazo, M. C., Hernández Freire, A. P., Jordán Buenaño, C. del R., \& Vera de la Torre, A. J. (2023). Boosting the English writing competence through the use of discourse connectors . ConcienciaDigital, 6(1.4), 91-108. https://doi.org/10.33262/concienciadigital.v6i1.4.1988




\section{Palabras claves: conectores discursivos, coherencia, cohesión, instrucción implícita y explícita, competencia escrita.}

\section{Keywords: discourse connectors, coherence, cohesion, implicit and explicit}

Resumen

Introducción. Los conectores discursivos son elementos lingüísticos cuyo objetivo principal es unir oraciones y dotar de fluidez al texto. Objetivo. El presente estudio investiga la relación entre los conectores discursivos y el mejoramiento de la competencia escrita en los estudiantes de tercer semestre de la Carrera de Pedagogía de los Idiomas Nacionales y Extranjeros, en el período académico octubre 2020 - febrero 2021. Metodología. La investigación fue cualitativa y cuantitativa, de tipo transversal correlacional con un diseño experimental y revisión literaria de las variables. La población estuvo conformada por 30 estudiantes de la Carrera de Pedagogía de los Idiomas Nacionales y Extranjeros, 12 mujeres y 18 hombres, de entre 20 y 24 años. Para recolectar la información se elaboró una encuesta con 23 preguntas la cual fue validada por dos expertos en el campo de la escritura. Valoraron la validez, la pertinencia y la coherencia. Los resultados de la encuesta permitieron establecer las estrategias y actividades para enseñar los conectores discursivos. Los participantes también recibieron una prueba previa de escritura independiente, tomada de la Universidad de Cambridge y evaluada con una rúbrica proporcionada por la misma universidad. Luego, con la información obtenida se elaboró una guía didáctica y los estudiantes tuvieron la oportunidad de aprender y practicar los conectores discursivos durante dos meses. Finalmente, se aplicó una prueba posterior para medir la relación de los conectores discursivos y la mejora de la competencia escrita. Resultados. Con la ayuda de las estadísticas se comparó la pre y post prueba. El estudio mostró que los estudiantes usan la puntuación y la ortografía correcta, Adicionalmente, eligen el conector apropiado. Además, eligen el lugar correcto del conector dentro de la oración. Finalmente, sus párrafos contienen oraciones temáticas con idea de control, ideas de apoyo y conclusiones. En consecuencia, mejoraron la competencia de escritura.

\section{Abstract}

Introduction. Discourse connectors are linguistic elements which main aim is to join sentences and provide fluency to the text. Objective. The present study investigates the relationship between discourse connectors and the improvement of the writing competence in the students of third semester at Carrera de Pedagogy de los Idioms Nationals y Estrangers, October 2020 - February 
instruction, writing competence.
2021 academic period. Methodology. The research was qualitative and quantitative, cross-sectional correlational type with an experimental design and a literary review of the variables. The population consisted of 30 students from Carrera de Pedagogy de los Idioms Nationals y Estrangers, 12 women and 18 men, they were between 20 and 24 years old. To collect the information, a survey with 23 questions was elaborated which was validated by two experts in the writing field. They rated validity, relevance and coherence. The results from the survey allowed to establish the strategies and activities to teach the discourse connectors. Participants were also given an independent writing pre-test taken from the University of Cambridge and assessed with a rubric provided by the same university. Then, with the information obtained, a didactic guide was developed and the students had the opportunity to learn and practice the discourse connectors for two months. Finally, a post-test from the same university was applied to measure the relationship of discourse connectors and the improvement of writing competence. Results. With the help of the statistics the pre and post writing test were compared. The study showed that students use the correct punctuation and spelling and choose the correct DCs. Moreover, they choose the correct place of DCs within the sentence. Furthermore, their paragraphs contain topic sentences with controlling idea, supporting ideas and conclusions. Consequently, they improve their writing competence.

\section{Introduction}

The occurrence of coherence and cohesion of ideas is one of the prerequisites for defining a text as intelligible. Discourse connectors are linguistic components that assist in achieving this key characteristic of a text. According to Dressler and De Beaugrande (1997), writers must use DCs to assist their readers. They also mention that DCs help to increase communication comprehension by preventing misconceptions and ensuring that sentences are connected properly.

Consequently, it is important to know some of the problems students face now to write to help them to became writers competent. Shastri (2010), explains in her book Communicative Approach to teaching English as a second language, that the most common problems students face when writing are spelling, vocabulary, sentence structure, punctuation, correct layout, coherence and cohesion, organization of content 
and sequencing of ideas, sentence connectors, and the ability to communicate convincingly using various writing functions.

Knowing that Daif-Allah and Albesher (2013), propose that one important principle for improving students' academic writing is to teach them discourse connectors as a condition for improving their writing fluency, and that the teacher should provide supplementary materials to help students practice DCs. Finally, Sadeghi and Kargar (2014), stated that explicit instruction aids in the acquisition of discourse connectors.

Therefore, the main objective of this research study is to analyze the relationship between discourse connectors and the improvement of writing competence. For this purpose, a didactic guide was elaborated to teach the writing process and discourse connectors using the intrinsic and extrinsic teaching strategy. The didactic guide contains interested reading passages about culture, art, tourism and social matters. Additionally, with the help of some applications such as Nearpod, quizzes and written dim prove applications students keep interested and motivated to practice the writing skill.

Through the years discourse connectors have received many names such as: cohesive devices, cohesive elements (Halliday \& Hasan, 1976). Conjunctive adverbials / adverbs, connecting, adverbs, connecting words and phrases, connectives, connective adjuncts, connective adverbs, connectors, conjuncts, connectives, discourse connectors (Cowan, 2008; Prommas \& Sinwongsuwat, 2011). Words of connection, words of transition, logical connectors and meta discourse markers. Despite that, for the purposes of this study, the term discourse connectors will be used.

A discourse connector's primary function is to indicate the connection between passages (Biber et al., 2002). Furthermore, Prommas and Sinwongsuwat (2011) define discourse connectors as words or phrases that connect information in one clause to information in a previous clause. They are also regarded as linguistic cues because they aid in text interpretation by signaling the relationship between prior and subsequent segments.

Moreover, Discourse Connectors are explored using three different approaches: Schiffrin and Hamilton (2003) coherence approach, Fraser's (1988) the grammatical pragmatic perspective and Halliday and Hasan (1976) systemic functional grammar approach. One of the functions of discourse connectors, according to Schiffrin, is to provide coherence to the text. Furthermore, according to Fraser, the purpose of DCs is not just to offer coherence to the text, but also to connect the first and second utterances. The other role of DCs, according to Halliday and Hasan, is to offer meaning construction. It implies that the speaker must be very cautious now to select DCs to achieve cohesion in their writing.

DCs are characterized by their flexibility. This means that they can appear at the beginning, middle, or end of a sentence (syntax,). However, the most usual place is at the 
start of the phrase to indicate that additional information will follow. When it comes to semantics, when they are eliminated from the discussion, they have no impact on the meaning of ideas. They are derived from verbs, prepositions, and modal words, among other terms of lexis.

There are numerous categories and taxonomies of discourse connectors, however they are still incomprehensible. That is why, for this research work the classification of Rezvani et al. (2012), has been chosen since it offers a current taxonomy to aid comprehension and application of DCs.

Table 1

Classification of discourse connectors

\begin{tabular}{|c|c|c|}
\hline 1. Sequential DCs & a. Ordering & first, firstly, second, secondly, third, thirdly \\
\hline & & $\begin{array}{l}a, b, c \\
\text { one, two, three } \\
\text { in the first place, in the second place } \\
\text { first, second } \\
\text { for one thing, for another thing } \\
\text { to begin with, to start with }\end{array}$ \\
\hline & b. Timing & $\begin{array}{l}\text { in the end, at the same time, in the meantime, meanwhile, } \\
\text { meantime, simultaneously, initially, before, } \\
\text { earlier, previously, formerly, recently, not long ago, at } \\
\text { present, presently, currently, now, by now, until, } \\
\text { today, immediately, at the same time, during, all the while, } \\
\text { in the future yesterday, tomorrow, henceforth, } \\
\text { after, after a short time, after a while, soon, later, later, } \\
\text { following, the following week, suddenly, } \\
\text { all at once, instantly, immediately, quickly, directly, soon, } \\
\text { as soon as, just then, when, sometimes, } \\
\text { some of the time, occasionally, rarely, seldom, } \\
\text { infrequently, temporarily, periodically, gradually, } \\
\text { eventually, little by little, slowly, while, always, all the } \\
\text { time, without exception, at the same time, } \\
\text { repeatedly, often, frequently, generally, usually, if, never, } \\
\text { not at all, last, lastly, last of all, } \\
\text { to conclude, as a final point, finally, at this point, from now } \\
\text { on, henceforward, here, hitherto, up to now }\end{array}$ \\
\hline
\end{tabular}


Table 1

Classification of Discourse Connectors (continuation)

\begin{tabular}{|c|c|c|}
\hline & c. Transitional & $\begin{array}{l}\text { by the by, by the way, incidentally, now, eventually, } \\
\text { meanwhile, originally, subsequently }\end{array}$ \\
\hline \multirow[t]{2}{*}{ 2. Additive DCs } & a. Equative & $\begin{array}{l}\text { correspondingly, equally, likewise, similarly, in the same } \\
\text { way, by the same token, too, in (just) this way }\end{array}$ \\
\hline & b. Reinforcing & $\begin{array}{l}\text { again, also, further, furthermore, more, moreover then, too, } \\
\text { what is more, in addition, } \\
\text { above all, on top of it all, to top it off, to cap it, on top of } \\
\text { that, to crown it all, additionally, alternatively } \\
\text { and, and, besides, neither, nor, not...either, or, or else, as } \\
\text { well }\end{array}$ \\
\hline 3. Summation DCs & \multicolumn{2}{|c|}{$\begin{array}{l}\text { altogether, overall, then, therefore, thus, (all) in all, in conclusion, in } \\
\text { sum, to conclude, to sum up, to summarize, finally, in summary, } \\
\text { anyway, briefly, in short, to get back to the point, to resume, in a word. }\end{array}$} \\
\hline 4. Apposition DCs & \multicolumn{2}{|c|}{$\begin{array}{l}\text { Namely (viz), thus, in other words, for example, as an example, for } \\
\text { instance, that is (i.e.), that is to say, specifically, more precisely, } \\
\text { what is to say, for one thing, to put it another way, to put it } \\
\text { bluntly/mildly, what I am saying is, what I mean is, which is to } \\
\text { say, in this case, to illustrate, such as, to demonstrate, as revealed } \\
\text { by, to show, suppose that, specifically, to be exact, as illustrated } \\
\text { by, indeed }\end{array}$} \\
\hline 5. Resultive DCs & \multicolumn{2}{|c|}{$\begin{array}{l}\text { accordingly, arising out of as a consequence, as a result, beside } \\
\text { from this, because, consequently, due to, for, for this purpose, } \\
\text { hence, for this reason, in consequence, in that case, in this respect, } \\
\text { in such an event, on account of, on this basis, or(otherwise), } \\
\text { otherwise, so, then, therefore, thus, under the circumstances, with } \\
\text { regard to, with this in mind, with this intention, somehow, of } \\
\text { course, to this end, arising out of this, lest }\end{array}$} \\
\hline 6. Contrastive DCs & a. Antithetic & $\begin{array}{l}\text { contrariwise, conversely, } \\
\text { instead, oppositely, then, on } \\
\text { the contrary, in contrast, by } \\
\text { contrast, by way if } \\
\text { contrast, in comparison, by } \\
\text { comparison, by way of } \\
\text { comparison, on the one } \\
\text { hand \& on the other hand, } \\
\text { although, albeit, } \\
\text { notwithstanding, but }\end{array}$ \\
\hline
\end{tabular}




\section{Table 1}

\section{Classification of discourse connectors (continuation)}

\begin{tabular}{|c|c|}
\hline & $\begin{array}{l}\text { anyhow, anyway, anyways, } \\
\text { besides, else, however, } \\
\text { nevertheless, nonetheless } \\
\text { (none the less), } \\
\text { notwithstanding, only, still, } \\
\text { though, yet, in any case, in } \\
\text { any event, at any rate, at all } \\
\text { events, for all that, despite } \\
\text { that, in } \\
\text { spite of it all, after all, at the } \\
\text { same time, all the same, } \\
\text { admittedly, still and all, that } \\
\text { said, despite that, then } \\
\text { again, whereas, while, } \\
\text { whilst, in fact, actually, as a } \\
\text { matter of fact, }\end{array}$ \\
\hline & $\begin{array}{l}\text { better, more accurately, } \\
\text { more precisely, alias, } \\
\text { alternatively, in another } \\
\text { words }\end{array}$ \\
\hline & $\begin{array}{l}\text { again, alternatively, rather } \\
\text { better, worse, on other hand, } \\
\text { I mean, at least }\end{array}$ \\
\hline 7. Comparison DCs & $\begin{array}{l}\text { as...as, more...than, less...than, as (like), as if, as though, unlike, } \\
\text { in the same way, similarly, as well as, in much the same way, } \\
\text { resembling, parallel to, same as, identically, of little difference, } \\
\text { equally, matching, also, exactly, in relation to }\end{array}$ \\
\hline 8. Conditional DCs & $\begin{array}{l}\text { Whether...or not, if, only if, unless, even if, whether, provided } \\
\text { (that), in case, in the event(that) }\end{array}$ \\
\hline $\begin{array}{l}\text { 9. Generalization } \\
\text { DCs }\end{array}$ & $\begin{array}{l}\text { Overall, in general, generally, as a rule, in most cases, broadly } \\
\text { speaking, to some extent, mostly, above all, chiefly, largely, } \\
\text { primly, usually, essentially }\end{array}$ \\
\hline 10. Emphasizing DCs & $\begin{array}{l}\text { above all, after all, indeed, as a matter of fact, the main issue is, } \\
\text { chiefly, especially the most significant, } \\
\text { the chief characteristic, the major point, the most necessary, } \\
\text { extremely, to emphasize, to highlight, to stress, by all means, } \\
\text { undoubtedly, more importantly, most important of all, most of all, } \\
\text { moreover, furthermore, significantly, without a doubt, certainly, } \\
\text { to be sure, surely, absolutely, obviously, more and more, of major } \\
\text { interest, to culminate, in truth, the climax of, to add to that, without } \\
\text { question, unquestionably, as a result, probability, basically }\end{array}$ \\
\hline
\end{tabular}




\section{Table 1}

\section{Classification of discourse connectors (continuation)}

\begin{tabular}{ll}
\hline 11. Corroborative & actually, as a matter of fact, in fact, as it happens, at any rate, in \\
DCs & actual fact, in actual fact, in any case, in either case, in reality, to \\
& tell the truth, that is to say, of course, apparently, well, surely, \\
& frankly, honestly, I assume, I suppose, no doubt, I am afraid, to \\
& tell the truth, in my opinion, I believe, to be truthful, unfortunately \\
\hline
\end{tabular}

Source: Rezvani et al. (2012)

The table above depicts Rezvani et al. (2012) classification of Discourse Connectors, which is based on DCs' prior and recent literature research undertaken by other authors, as well as their own experience as users. Then, some concepts and examples are presented to make their application more evident.

1. an Ordering: They are used to put a process or a sequence in chronological order.

Ex: First, decide on a topic then brainstorm ideas.

1. $b$ Timing: These kinds of DCs are often used to add energy to the sequence of ideas and to mention the frequency of an activity.

Ex. My father was cooking. Meanwhile, I cleaned my room.

1. c Transitional: These discourse connectors are helpful to change the topic of a sentence. Most of the time, the shift is related with the first sentence. about?

Ex. We had spent some time in this conference. By the way, what was the topic

2. Additive DCs: These kinds of connectors add additional information to the preceding idea. In this research study, two are mentioned.

2. a Equative DCs: These are used to indicate that the after sentence has the same importance as the preceding one.

Ex. She can play the piano very well and the guitar, too.

2. b Reinforcing DCs: These types of connectors help to emphasize the information previously mentioned.

Ex. Throughout my professional life, I have always attempted to be competent, helpful, and, above all, to maintain my integrity.

3. Summation DCs: The main objective of these kinds of connectors is to summarize the information mentioned in the discourse. 
Ex. In short, the main objective of discourse connectors is to add coherence to the text.

4. Appositions DCs: These types of connectors are used to give examples or restate the information explained.

Ex. Students who pretend to improve their English pronunciation must listen and sing songs. To put it in another way, they must use the language in every situation.

5. Resultive DCs: These are used to indicate the cause and result of the preceding information.

Ex. Because of the pandemic, unemployment has increased around the world.

6. Contrastive DCs: These types of DCs are used to introduce information which is opposite or involve surprise from previous info. Within this category, there are four subtypes.

6. an Antithetic DCs: These are used to contrast information with previous data.

Ex. My father promised to buy a new car. Although, we continued with the same old one.

6. b Concessive DCs: These types of connectors are used to show unexpected information.

Ex. She has worked very hard. Still, she did not get a promotion at her company.

6. c Reformulatory DCs: These types of DCs are used to show contrast by reformulating the idea.

Ex. He has called me many times, more precisely, twelve times.

6. $d$ Replacive DCs: These ones let to change one idea for a more important one.

Ex. His registration to the army was opposed by his wife, or, rather, by his parents and wife.

7. Comparison DCs: These discourse connectors are used to emphasize or indicate similarities between objects.

Ex. I can speak Spanish as well as English.

8. Conditional DCs: These types of DCs are used to show a condition to fulfill an action.

Ex. You can stay at my house if you do not have covid. 
9. Generalization DCs: These types of DCs are used to say that a statement is true in most situations.

Ex: In most cases, it is cold in Ambato at night.

10. Emphasizing DCs: These types of discourse connectors are used to add emphasis on something already mentioned.

Ex: I thought this jacket was $\$ 20$, actually, is $\$ 40$.

11. Corroborative DCs: These types of discourse connectors are used to strengthen an argument.

Ex: I believe that the prison problem is not only a matter for the president, but it is also for all governments.

It was observed during the bibliographic research that DCs have been given a variety of names, including DMs, linking words, connectives, discourse operators, and DCs, among others. They are studied as DCs in this research because they connect textual information. Furthermore, they are adaptable and can communicate the following ideas in a text: reason, addition, contrast, sequence, summation, apposition, result, comparison, condition, generalization, collaboration, and emphasis.

It is emphasized, that to become a successful writer, learners must be able to control the three characteristics of writing: the mechanical, the linguistic, and the communicative one (Shastri, 2010). So, it implies that a good writer should master these three qualities of writing: spelling, vocabulary, sentence structure, punctuation, a proper layout, coherence and cohesiveness, and the clear and logical structuring of content are all part of writing skills. And sub-skills such as concept organization and sequencing, sentence connection, and the capacity to communicate effectively utilizing various writing's functions. Finally, a competent writer must understand the reader, as well as a feeling of purpose and connection between ideas.

It is also important to mention that DCs provide coherence to a written text, which is obtained when sentences are connected logically and the right DCs are used to construct the text. When phrases, sentences, and paragraphs make sense, they form a logical relationship. DCs also provide coherence to a document (Dulger, 2007), because they allow sentences to flow logically into one another.

It is suggested to use the implicit an explicit teaching to teach discourse connectors since the implicit instruction permits to teach without translating their meaning or explaining their syntactic position or function of the sentence. The teacher's job is to plan a series of activities that are logically arranged and methodically planned, while the students' job is 
to deduce some linguistic properties of DCs. It's also a good idea to offer explicit instruction because some discourse connectors are tough to figure out what they represent. Consequently, the teacher must explain what DCs are and how to use them (Lee \& Jung, 2005).

There are some recommended ways for teaching discourse connections that have proven to be effective. Consciousness raising, an emphasis on form, a focus on the environment, open-ended practice, and a theme to be developed are a few of them.

Consciousness Raising: This method aims to raise learners' awareness of DCs. Students' capacity to infer, compare, and observe distinctions among DCs can be developed through activities that the lecturer can use.

Focus on form. - The major goal of this method is to improve students' grammatical skills in communication.

Pay attention to the environment. This method can be utilized by the teacher to help leaners understand that discourse connectors are only employed in certain situations.

This is an open-ended exercise. The goal of this method is for students to connect sentences using a discourse connector.

Given topic to be developed. - The major goal of this method is to have students produce an essay with an introduction, body, and conclusion, as well as to have them use discourse connectors in their writing.

Focusing on functions. This technique can be used by the teacher to teach discourse connectors based on their semantic linkages, for example, cause and effect discourse connectors.

Underuse, overuse, and misuse of discourse connectors are some of the most common issues students experience when writing fluently (Mateus, 2016). Furthermore, students face internal and external writing challenges. The former is linked to issues with syntax, cognition, and sentence structure, as well as a lack of motivation and word choice and vocabulary. The learners' external difficulties are caused by a lack of practice, which is caused by their laziness and motivation to practice. It is also stated that teachers do not provide adequate feedback to students on their written work. It means that teachers assign a grade to students without remarking on their writing errors. According to the study, students utilized the following tactics when writing in English: $76 \%$ of students think in Spanish first and then translate their ideas into English.

In addition, some other studies found that when students write in the target language, their L1 causes significant interference. Some common sources of interference were invented 
words, adjective position, and word order. The following factors, on the other hand, had the lowest frequency: mistaken cognates, abuse of comparatives and superlatives, and gender forms.

\section{Methodology}

This research project is supported by a mixed approach. It refers to both qualitative and quantitative methods. The former one allowed researcher to gather data on why students misuse, underuse, and overuse discourse connections. And quantitative because the statistics was used to examine the data collected. According to Kothary (2004), qualitative data collection is exploratory, allowing for in-depth interpretation of the data. He added that qualitative data cannot be measured and that data collection tools for small groups are preferable. Quantitative research, on the other hand, can quantify data and is better suited to large groups. Furthermore, the information was collected through a survey which was validated by two experts and then applied to students as well as teachers. The analysis of the information was done using the statistics.

\section{Sample}

The present study aims to analyze a population of 30 students of 20 and 24 years old, 12 women and 18 men who studied the writing module in Pedagogy of Idioms Nationals y Estrangers.

\section{Procedure}

The compilation of the data was carried out through a survey that was elaborated and validated by two specialists, and later applied to students and teachers. The results allowed to establish the strategies and activities to teach and learn the discourse connectors. Participants were also given an independent writing pre-test taken from the University of Cambridge and assessed with a rubric provided by the same university.

\section{Qualitative approach}

On the one hand, 23 questions were developed to obtain information of students.

\section{Quantitative approach}

Participants were given an independent PET writing pre-test taken from the University of Cambridge and assessed with a rubric provided by the same university.

The independent writing pre-test from the University of Cambridge requested students to write an essay about their last vacation. The Rubric to evaluate the had four indicators: 1) content, 2) grammar, 3) vocabulary and 4) spelling and punctuation. With a scale from 5 to 1 , five as the maximum and 1 as the minimum. 


\section{Results}

After analyzing the pre-test's results, which requested students to write an essay about their most recent vacation. The results were the following.

\section{Figure 1}

Misuse, underuse and overuse of DCs in the Pre-test

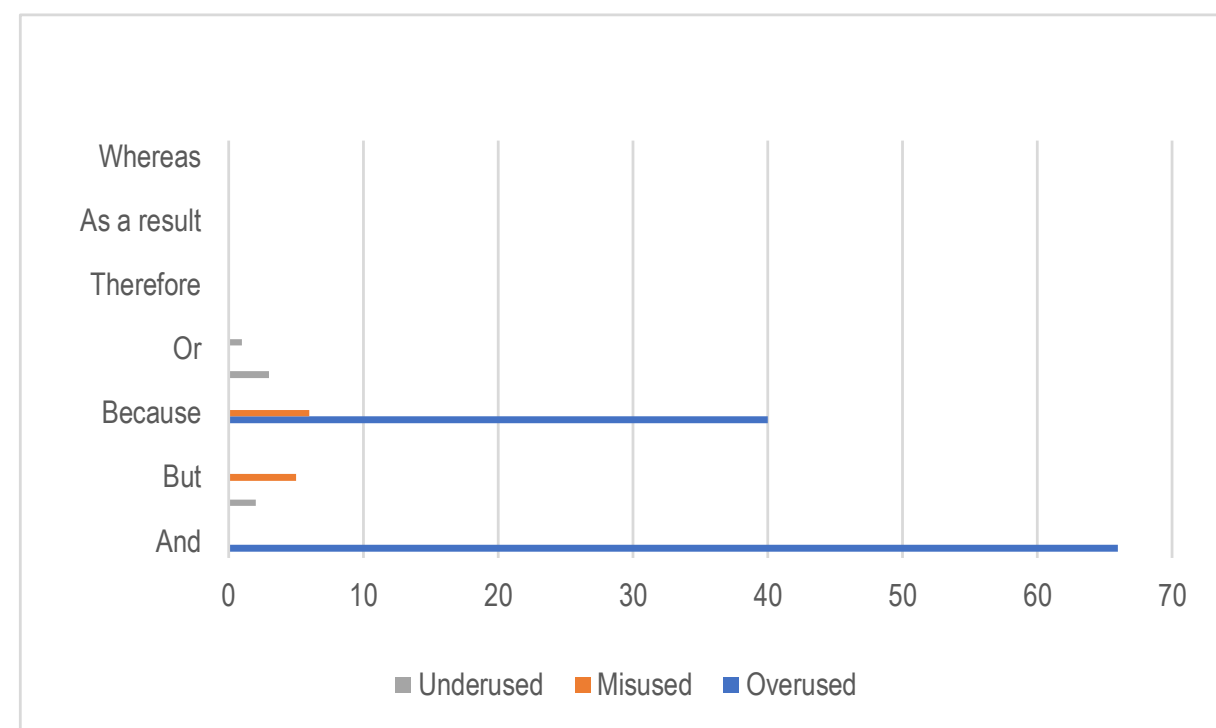

Note. Discourse Connectors that students from the third semester misuse, underuse and overuse.

Source: Pres-test

Analyzing the pre-test examination of the 30 students' writings, it was discovered that most of them use discourse connectors such as and because to connect sentences. It also showed that few students employ but and because, as well as other forms of discourse connectors. Some students don't utilize any DCs at all in their papers.

Most students (63\%) employ DCs and to unite two similar sentences and adjectives. However, most of them (90\%) do not employ it with the proper punctuation, it was also discovered that each student's essay contains at least three times this DC. According to Zemach \& Rumisek (2005), when two independent sentences are connected, a comma is required, when an independent sentence and a dependent sentence are joined a comma is omitted. Furthermore, when two adjectives are combined, a comma is not required, but when three adjectives are combined, a comma is required between the first and second adjective.

Concerning the correct use of but, students have average knowledge about it. Since not all the students use but to join two contrastive ideas. Moreover, but is underuse because it was noticed that few students use this DC. Additionally, students do not use the correct punctuation. According to Zemach \& Rumisek (2005), a comma needs to be used when 
two independent sentences are joined. The comma is omitted when it joins an independent sentence with a dependent one.

The results about the DC because, shows that it is overused, and that, not all the students use it to explain causes. About punctuation, students do not use the correct one. According to Zemach \& Rumisek (2005), it is necessary to use a comma when a sentence starts with because, at the end of the first sentence, and it is omitted when because is placed in the middle of the sentence.

Students also have issues with sentence construction and grammar. The language structure is incoherent, making their thoughts difficult to comprehend. They also have issues with spelling. It was discovered that this is due to influence from the L1 language. Furthermore, they do not employ proper punctuation, particularly when ending a statement. They forget to finish a sentence with a period. They also write very long sentences because of the L1 sentence structure. Students in the Spanish language write extended sentences, which is different in English. The sentences in English are not particularly long.

Furthermore, not all students include a topic sentence in the paragraph with controlling idea. Furthermore, they neglect to include supporting concepts and examples. The text is disorganized, and at the end of each paragraph, they forget to put a concluding sentence.

To sum up, learners misuse DCs and because. They misuse but and because, as well as underuse also, so, therefore, consequently, as a result, whereas, and for example. Students should also work on improving their punctuation when using DCs and expanding their vocabulary about them.

After the pre-test, several lessons were implemented to assist students in correcting the errors discovered during the test. Those cover sentence structure and punctuation, topic sentences and controlling idea, supporting information, concluding sentences, DCs (and, but, because, so, therefore, whereas, and as a result), the writing process, and some capitalization rules using the Nearpod, quizzes and writeandimprove apps.

After the treatments, a post-test was applied to assess the students' improvement in writing competence. The outcomes are displayed below. 


\section{Figure 2}

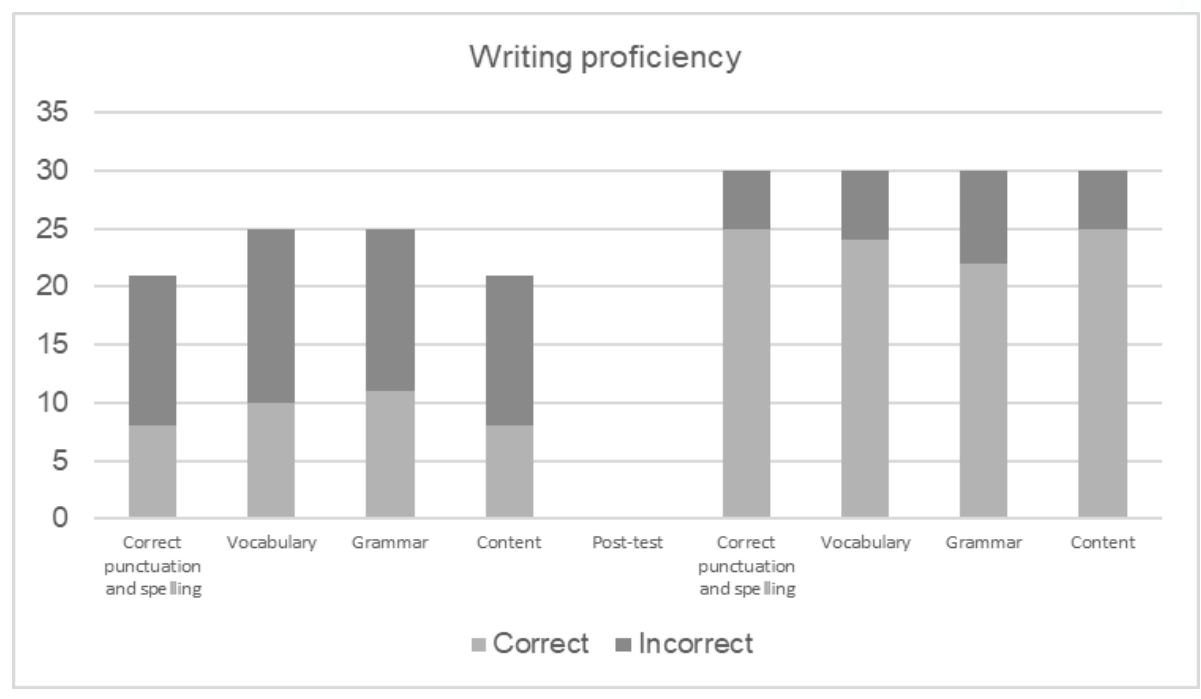

Note. It shows students' writing proficiency in terms of writing proficiency Source: Post-test

According to the results, students' writing proficiency improved. The sentences, as well as the paragraphs, were logically ordered, making it easy to understand their ideas. They also reduced spelling issues. Furthermore, most of the students capitalized the words correctly. Moreover, they choose the correct DCs and place them in the right place with the correct punctuation. In addition, students use different DCs from each DCs' classification. Finally, the paragraphs contain topic sentence with controlling idea, supporting ideas and conclusion.

\section{Conclusions}

- After Teaching DCs to students of the third semester of the Carrera de Pedagogy de los Idiom's nationals y estrangers, the following conclusions can be mentioned.

- Discourse connectors can help students improve their writing skills by allowing ideas to flow freely, increasing communication understanding, and ensuring that ideas are connected properly.

- Student's overuse DCs such as and, so and because in their writing. It was also discovered that a small percentage of students misuse the words but and because. Furthermore, students underuse therefore, consequently. Finally, it was discovered that many students do not include any CDs in their written work.

- Students may misuse DCs for a variety of reasons, they do not the meaning of some DCs. Furthermore, they are unsure of their place in the sentence and do not know the correct punctuation of them. Furthermore, students underuse discourse 
connectors because they are not persuaded to use new ones or are not exposed to them.

- Discourse Connectors were taught utilizing implicit and explicit teaching methods, which helped students enhance their writing skills by facilitating their learning. They were able to write sentences with proper grammar, increase coherence and cohesion, punctuation, and effectively explain concepts.

\section{Bibliographical references}

Biber, D., Conrad, S. \& Leech, G. (2002). Longman Student Grammar of Spoken and Written English. Harlow, Essex: Pearson Education Limited.

Cowan, R. (2008). The teachers' grammar of English. Cambridge: Cambridge University Press.

Daif-Allah, A. \& Albesher, K. (2013). "The use of discourse markers in paragraph writings: the case of preparatory year program students in Qassim University. Saudi Arabia: Canadian Center of Science and Education". English Language Teaching, 6/9: 217-227.

Dressler, U \& De Beaugrande, R. (1997). Introducción a la lingüística del texto. En R.A. d. Dressler, Introducción a la lingüística del texto. España: Ariel.

Dulger, O. (2007). Discourse markers in writing. Seluck University Sosyal Bilimler Enstitutus Dergis, 18: 257-270

Fraser, B., (1988). Types of English discourse markers. Acta Lingüística Hungarica, 38(14): $19-33$.

Halliday, M., \& Hasan, R. (1976). Cohesion in English. London: Longman.

Kothary, C. (2004). Research methodology. India, Jaipur: New age international publishers.

Lee, B. \& Jung, C. (2005). Discourse Marker Teaching in College Conversation Classrooms: Focus on well, you know, I mean. Cambridge: Cambridge University Press.

Mateus, T. (2016). Teaching Discourse Connectors to Help 2nd Year Students. (Undergraduate thesis). Instituto Superior de Ciências de Educação da HuílaiscedHuíla Departamento de Letras Modernas Secção de Inglês, Lubango. 
Prommas, P. \& Sinwongsuwat, K. (2011). A comparative study of discourse connectors used in argumentative compositions produced by Thai EFL learners and Englishnative speakers. The 3rd International Conference on Humanities and Social Sciences, 1-17

Rezvani, S., Abdullah, A., Mukundan, M. \& Tannacito, D. (2012) Discourse Connectors: An Overview of the History, Definition and Classification of the Term. World Applied Sciences Journal, 19, 1659-1669. Doi: 10.5829/idosi.wasj.2012.19.11.1990

Sadeghi, B. \& Kargar, A. (2014). "The effect of explicit instruction of discourse markers on EFL learners' writing ability." International Journal of Educational Investigations, 1/1: 328-338.

Schiffrin, D., D. \& Hamilton, H. (2003). The handbook of discourse analysis. WileyBlackwell.

Shastri, D. (2010). Communicative Approach to the Teaching of English as a Second Language. Himalaya Publishing House.

Zemach, D. \& Rumisek, L. (2005). Academic Writing: from Paragraph to Essay. London: Macmillan Publishers Limited

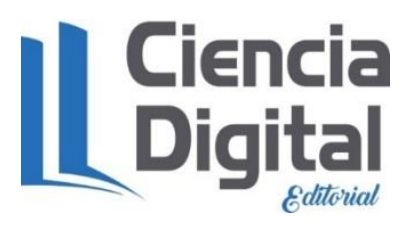


El artículo que se publica es de exclusiva responsabilidad de los autores y no necesariamente reflejan el pensamiento de la Revista Conciencia Digital.

\section{Ciencia}

El artículo queda en propiedad de la revista y, por tanto, su publicación parcial y/o total en otro medio tiene que ser autorizado por el director de la Revista Conciencia Digital.
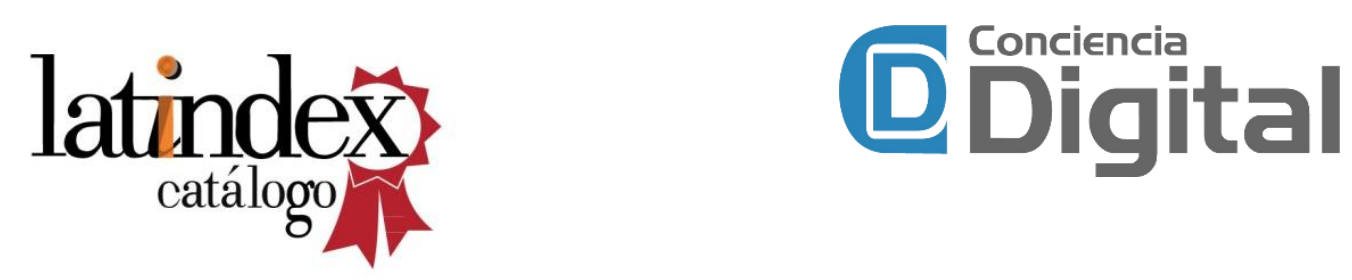

Indexaciones

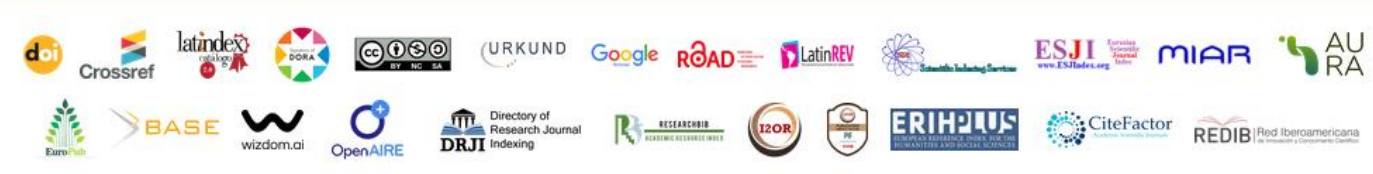

